\title{
Development and Evaluation of Pedotransfer Functions to Estimate Soil Moisture Content at Field Capacity and Permanent Wilting Point for South African Soils
}

\author{
Lindumusa Myeni ${ }^{1, *}$, Thandile Mdlambuzi ${ }^{2}{ }^{\mathbb{D}}$, David Garry Paterson ${ }^{1}$, Gert De Nysschen ${ }^{1}$ \\ and Mokhele Edmond Moeletsi 1,3 (i) \\ 1 Agricultural Research Council-Natural Resources and Engineering, Private Bag X79, Pretoria 0001, \\ South Africa; Garry@arc.agric.za (D.G.P.); Gert@arc.agric.za (G.D.N.); MoeletsiM@arc.agric.za (M.E.M.) \\ 2 South African Sugarcane Research Institute, Private Bag X02, Mount Edgecombe 4300, South Africa; \\ Thandile.Mdlambuzi@sugar.org.za \\ 3 Risk and Vulnerability Assessment Centre, University of Limpopo, Private Bag X1106, Sovenga 0727, \\ South Africa \\ * Correspondence: MyeniL@arc.agric.za
}

check for updates

Citation: Myeni, L.; Mdlambuzi, T.; Paterson, D.G.; De Nysschen, G.; Moeletsi, M.E. Development and Evaluation of Pedotransfer Functions to Estimate Soil Moisture Content at Field Capacity and Permanent Wilting Point for South African Soils. Water 2021, 13, 2639. https: / / doi.org/10.3390/w13192639

Academic Editor: Guy Roth

Received: 3 August 2021

Accepted: 17 September 2021

Published: 25 September 2021

Publisher's Note: MDPI stays neutral with regard to jurisdictional claims in published maps and institutional affiliations.

Copyright: (c) 2021 by the authors. Licensee MDPI, Basel, Switzerland. This article is an open access article distributed under the terms and conditions of the Creative Commons Attribution (CC BY) license (https:/ / creativecommons.org/licenses/by/ $4.0 /)$.

\begin{abstract}
This study was undertaken to develop new pedotransfer functions (PTFs) for the estimation of soil moisture content at field capacity $(\mathrm{FC}$, at $-33 \mathrm{kPa})$ and permanent wilting point (PWP, at $-1500 \mathrm{kPa}$ ) for South African soils based on easily measurable soil physico-chemical properties. The new PTFs were developed using stepwise multiple linear regressions with the dependent variable (either FC or PWP) against clay, silt, sand and soil organic carbon (SOC) content from a total of 3171 soil horizons as the explanatory variables. These new PTFs were evaluated and compared with five well-established PTFs using a total of 3136 soil horizons as an independent dataset. The coefficient of determination $\left(r^{2}\right)$ values for the existing PTFs ranged from 0.65-0.72 for FC and 0.72-0.81 for PWP, whilst those developed in this study were 0.77 and 0.82 for FC and PWP, respectively. The root mean square error (RMSE) values for the well-established PTFs ranged from $0.052-0.058 \mathrm{~kg} \mathrm{~kg}^{-1}$ for FC and $0.030-0.036 \mathrm{~kg} \mathrm{~kg}^{-1}$ for PWP, whilst those developed in this study were 0.047 and $0.029 \mathrm{~kg} \mathrm{~kg}^{-1}$ for FC and PWP, respectively. These findings suggest that PTFs derived locally using a large number of soil horizons acquired from different agro-climatic locations improved the estimation of soil moisture at FC and PWP. Due to the range of conditions and large soil datasets used in this study, it is concluded that these new PTFs can be applied with caution in other regions facing data scarcity but with similar soil types and climatic conditions.
\end{abstract}

Keywords: modelling; multiple linear regressions; soil hydraulic properties; soil physico-chemical properties; validation

\section{Introduction}

There has recently been increasing interest in the accurate modelling of water dynamics in soil-plant-atmosphere systems within the context of climate change modelling and adaptation [1]. Within this context, biophysical models such as Aquacrop [2], APSIM [3], CropSyst [4], DSSAT [5], SPAW [6] and SWAT [7] are often applied to estimate crop yields, solute movements and irrigation water requirements. These biophysical models are also used for the assessment of water balance components such as drainage, runoff and evapotranspiration to support efficient management and allocation of resources in different countries of the world [1,8-12]. These models are therefore becoming more important to solve numerous water-related challenges posed by climate change in the fields of agriculture, ecology, environment, hydrology and soil sciences [13,14].

The application of biophysical models requires knowledge of soil hydraulic properties at a high spatial resolution, specifically the soil moisture content at field capacity 
(FC, at $-33 \mathrm{kPa}$ ) and permanent wilting point (PWP, at $-1500 \mathrm{kPa}$ ) for each soil horizon $[1,8,9,13,15-17]$. Water retention at FC and PWP are the two critical soil hydraulic properties that are required for the computation of plant-available water in the soil profile $[12,13,17]$. However, measurements of these soil hydraulic properties are expensive, labour-intensive, time-consuming and sometimes impractical or financially unattainable, especially for regional studies [8,13,18-22]. Furthermore, laboratory apparatus such as pressure plates that are used for the determination of these soil hydraulic properties are costly and are often unavailable in many developing countries $[18,23,24]$.

Alternatively, these soil hydraulic properties are often estimated using pedotransfer functions (PTFs) based on easily measurable soil properties that are readily available from soil surveys such as soil particle size distribution (sand, silt and clay), bulk density and soil organic carbon (SOC) content [11-13,17-19,24-28]. Generally, PTFs are developed using correlations between these readily available or easily measurable soil properties and measurements of water retention at different pressure heads. Many PTFs with different data input requirements have been developed and validated for the estimation of soil hydraulic properties $[9,20,25,26,28-38]$. Some of these PTFs have been incorporated into biophysical models such as Aquacrop, CropSyst, DSSAT, SPAW and SWAT amongst others as the ready-to-use PTFs to fill in missing information of soil moisture content at FC and PWP $[12,13,17]$.

Research on the evaluation of the existing PTFs has shown that they are often only reliable and applicable for regions with similar characteristics to those of their origins $[9,12,13,39-42]$. The limited transferability of PTFs across different regions is attributed to the significant variations in geological, climatic and soil bio-physico-chemical properties across regions $[14,18,43]$. Therefore, PTFs applied outside the soils and climatic conditions from which they were derived may result in poor performance $[8,13,18,20]$. Inaccurate estimation of hydraulic properties may result in the poor modelling of the water dynamics and could give misleading overall results from a biosphere model, resulting in inefficient use and management of natural resources $[12,13]$. Therefore, the existing PTFs developed internationally still need to be calibrated and validated locally against measurements before they can be reliably used to estimate hydraulic properties in new sites that are located in different regions from their origins [12,44-46]. However, the lack of representative information on soil hydraulic properties hinders the validation of the existing PTFs and the development of local PTFs in many countries of the world [12,24,46,47]. Consequently, the existing PTFs are often applied without any calibration or validation in many regions as the result of data constraints $[13,46,48]$. Therefore, the reliability of the estimated soil hydraulic properties from the existing PTFs in regions outside their origins with different geological, climatic and soil bio-physico-chemical properties is questionable.

Very few PTFs have been developed specifically for use within the agro-climatic conditions of Africa $[25,28,31,32]$, which is widely described as a major hotspot for climate change [49-52]. Thus, the need for accurate modelling of water dynamics is of utmost importance for efficient management and use of natural resources as water-related challenges posed by climate change are expected to increase in this region. Some work has been done to develop and evaluate PTFs to estimate water retention at different pressure heads for South African soils [28,53-56]. The major drawback of these earlier studies is that they used a limited number of samples $(<450)$ collected from a limited range of soil types and under specific climatic conditions. Therefore, the applicability and reliability of these existing PTFs for the estimation of water retentivity of the soils over a wide range of agro-climatic conditions in South Africa is questionable. Furthermore, most of these existing PTFs require measurements of bulk density as an input requirement, which is often not readily available from the soil surveys or is measured with difficulty, especially in developing countries [18]. Therefore, existing PTFs that require bulk density as an input variable may be of limited use in countries such as South Africa that are facing data constraints. 
For regions facing data constraints, the evaluation of the widely-used PTFs or development of local PTFs that can be reliably used to estimate soil water retention over a wide range of soil types and climate conditions without bulk density would be more beneficial for the improved estimation of water dynamics [26]. The availability of the South African national soil database of the Land Type Survey Staff [57] provided a unique opportunity to develop new PTFs that do not require bulk density data and to evaluate the performance of the existing PTFs over a wide range of soil types and climatic conditions of this country. Given the diversified nature of the southern Africa region in terms of climatological, biogeographical, pedological and lithological characteristics, this study is expected to reveal the strengths and weaknesses of the existing PTFs with the aim of improving them or developing new PTFs for better estimation of water retention in future studies. Therefore, this study aimed to improve the estimation of soil moisture content at FC and PWP from minimal soil physico-chemical properties that are usually available from surveys or easily measured in most countries of the world. The first objective was to develop new PTFs for the estimation of soil moisture content at FC and PWP for a wide range of soil types and climatic conditions in South Africa using the national soil database. These new PTFs were evaluated and compared with five well-established PTFs using an independent dataset to evaluate their applicability and reliability over a wide range of the most typical soil types and climatic conditions found in South Africa.

\section{Materials and Methods}

\subsection{Soil Database}

A total of 7219 soil horizons from 2800 profiles with measured gravimetric soil moisture content at FC $\left(\%, \mathrm{~kg} \mathrm{~kg}^{-1}\right)$, PWP $\left(\%, \mathrm{~kg} \mathrm{~kg}^{-1}\right)$, particle size distribution (\%) and soil organic carbon (SOC, \%) were extracted from the Agricultural Research Council of South Africa (ARC) soil database. The choice of these soil properties was based on the soil hydraulic and physico-chemical properties that are available from the South African national soil database of the Land Type Survey Staff [57]. The pressure plate apparatus was used to determine water retention at pressure heads of $33 \mathrm{kPa}$ and $1500 \mathrm{kPa}$ using disturbed soil samples. Five or seven original particle size classes (\%) were measured with the double pipette method, i.e., coarse sand $(2.0-0.5 \mathrm{~mm})$, medium sand $(0.25-0.5 \mathrm{~mm})$, fine sand $(0.10-0.25 \mathrm{~mm})$, and very fine sand $(0.05-0.10 \mathrm{~mm})$, coarse silt $(0.02-0.05)$, fine silt $(0.002-0.02 \mathrm{~mm})$ and clay $(<0.002 \mathrm{~mm})$ [58]. These particle size classes were then summed into three classes, i.e., sand $(2.0-0.05 \mathrm{~mm})$, silt $(0.05-0.002 \mathrm{~mm})$ and clay $(<0.002 \mathrm{~mm})$ [59]. The Walkley-Black method was used to determine the SOC content [60].

A data quality routine was undertaken to identify and eliminate obvious errors. For example, soil horizons with no geographical coordinates, negative values of soil moisture content at FC or PWP, soil moisture content at PWP greater than FC or total textural content of either below $95 \%$ or above $105 \%$. A similar data quality protocol was undertaken by Van Tol et al. [61] to clean datasets for the development and validation of pedotransfer functions for the estimation of Atterberg limits in South African soils. After this process, a total of 6307 soil horizons from different soil profiles, representing a wide range of soil types, geology, parent materials and climatic conditions found in South Africa, were used for the development and evaluation of PTFs in this study (Figure 1). The choice of these sites was based on the availability of quality data of water retentivity with corresponding particle size distribution and SOC. Rainfall is one of the key factors that significantly affects vegetation distribution [62-64] and is also one of the key agents of weathering, resulting in variation in soil types [65]. Thus, variations in long-term mean annual rainfall (from the year 1960 to 2020) were used as an additional indicator of the wide range of soil types in the dataset for this study (Figure 1). 


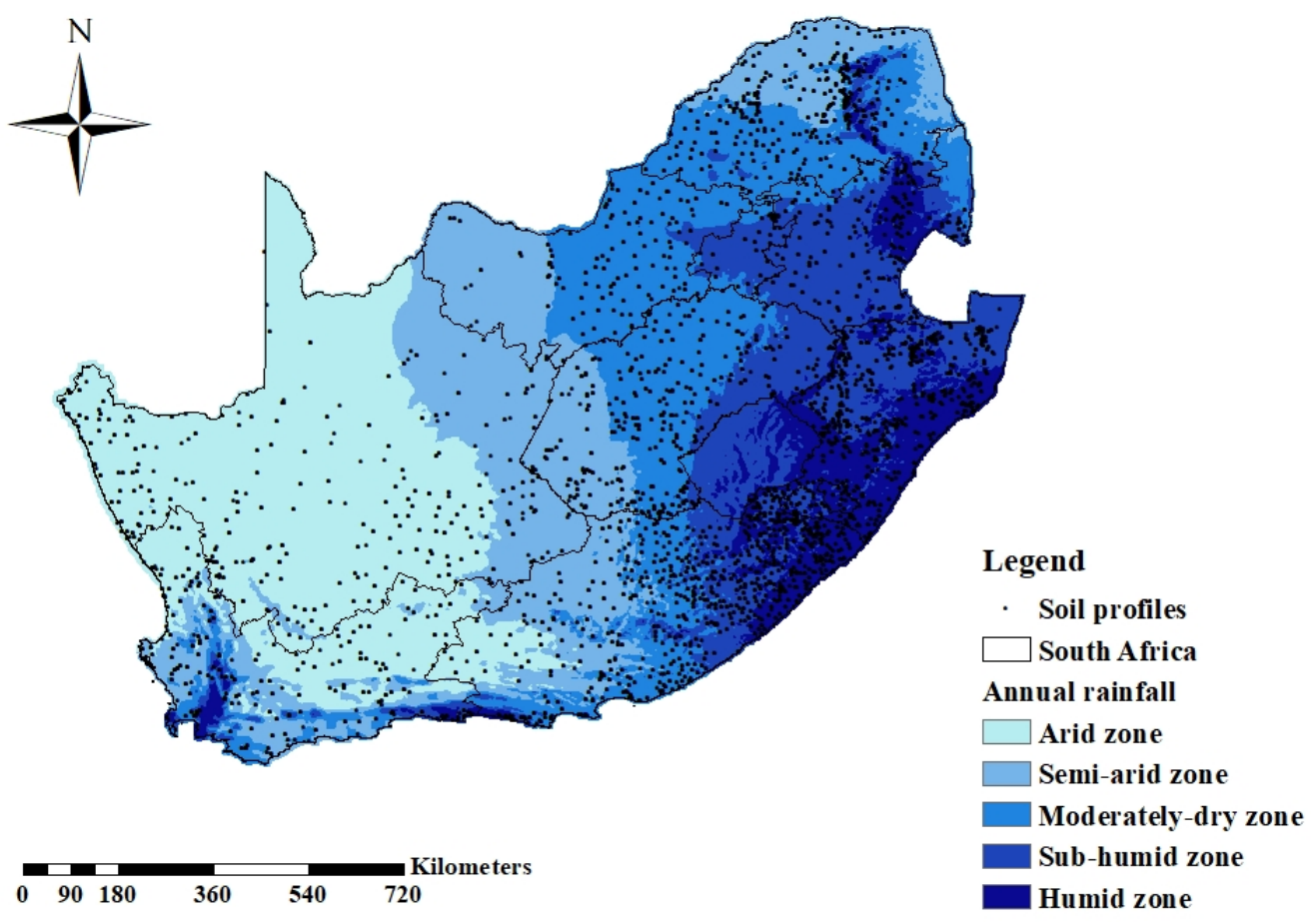

Figure 1. Long-term mean annual rainfall [66] and the location of soil profiles used in this study.

\subsection{Development of New PTFS}

Previous studies have reported improved performance of the PTFs that were developed using a large number of soil horizons acquired from different soil depths, soil types, geographic and climatic conditions of a specific region $[17,24,26]$. Therefore, in this study, a total of 6307 soil horizons were grouped regardless of their soil depth, soil type, textural class, geographic and climatic location then randomly divided per granulometric range into two groups, with one group used for the development of new PTFs and the other for validation of the PTFs. The new PTFs for estimating soil moisture at FC and PWP were developed using stepwise multiple linear regressions with the dependent variable (either soil moisture content at FC or PWP) against weight percentages of sand, silt, clay and SOC content as the explanatory variables. The highest coefficient of determination $\left(r^{2}\right)$ was used to select the best fit of the linear regression functions. A similar approach has been widely used to develop and validate PTFs $[9,17,26,29,37]$.

\subsection{Evaluation and Comparison of PTFs}

The new PTFs developed in this study were evaluated and compared with five wellestablished PTFs using an independent dataset (Table 1). The selection of the five existing PTFs was based on them being well established for the estimation of gravimetric soil moisture content at FC and PWP using only particle size distribution and SOC as the input requirements.

\subsection{Statistical Analysis}

The root mean square error (RMSE, $\mathrm{kg} \mathrm{kg}^{-1}$ ), mean bias error (MBE, $\mathrm{kg} \mathrm{kg}^{-1}$ ) and index of agreement $(d)$ were used for the evaluation of PTFs and were computed following the procedure of Willmott et al. [67]:

$$
\begin{aligned}
\text { RMSE } & =\sqrt{\frac{\sum_{i=1}^{n}\left(\mathrm{w}_{e i}-\mathrm{w}_{o i}\right)^{2}}{n}} \\
\mathrm{MBE} & =\frac{\sum_{i=1}^{n}\left(\mathrm{w}_{e i}-\mathrm{w}_{o i}\right)}{n}
\end{aligned}
$$




$$
d=1-\left[\frac{\sum_{i=1}^{n}\left(\mathrm{w}_{e i}-\mathrm{w}_{0 i}\right)^{2}}{\sum_{i=1}^{n}\left(\left|\mathrm{w}_{e i}-\overline{\mathrm{w}_{o}}\right|+\left|\mathrm{w}_{o i}-\overline{\mathrm{w}_{o}}\right|\right)^{2}}\right]
$$

where $i$ is the data pair index, $\mathrm{w}_{e}$ and $\mathrm{w}_{o}$ are estimated and measured gravimetric moisture content, respectively, while $\overline{\mathrm{w}_{o}}$ is the mean of $\mathrm{w}_{o}$ and $n$ is the number of observations. A linear regression between $\mathrm{w}_{e}$ and $\mathrm{w}_{o}$ values was also computed:

$$
\mathrm{w}_{e}=m \mathrm{w}_{o}+c
$$

where the slope $(m)$ was used as a measure of accuracy and $c$ is the y-intercept $\left(\mathrm{kg} \mathrm{kg}^{-1}\right)$. The coefficient of determination $\left(r^{2}\right)$ was used to quantifies the degree of the linear correlation, while the RMSE is the measure of the accuracy expressing the magnitude of the error in prediction. Based on these statistics, better performance of the PTFs is indicated by RMSE, MBE and $c$ values approaching zero whilst $d, r^{2}$ and $m$ values approach 1 [67].

Table 1. List of well-established PTFs for estimating soil moisture content at FC and PWP evaluated

\begin{tabular}{|c|c|c|c|}
\hline Source & Abbreviation & Output & $\begin{array}{l}\text { Geographical } \\
\text { Domain }\end{array}$ \\
\hline Arruda et al. [30] & $\mathrm{AR}$ & $\begin{array}{c}\mathrm{FC}=0.29 \times(\mathrm{Cl}+\mathrm{Si})+9.93 \\
\mathrm{PWP}=0.27 \times(\mathrm{Cl}+\mathrm{Si})+1.07\end{array}$ & Brazil \\
\hline Chakraborty et al. [33] & $\mathrm{CH}$ & $\begin{array}{c}\mathrm{FC}=27.447+(0.078 \times \mathrm{Cl})+ \\
(0.248 \times \mathrm{Si})-(0.241 \times \mathrm{Sa}) \\
\mathrm{PWP}=20.695+(0.021 \times \mathrm{Cl})- \\
(0.028 \times \mathrm{Si})-(0.179 \times \mathrm{Sa})\end{array}$ & India \\
\hline Dijkerman [25] & DI & $\begin{array}{c}\mathrm{FC}=0.3697-(0.0037 \times \mathrm{Sa}) \\
\mathrm{PWP}=0.0074+(0.0039 \times \mathrm{Cl})\end{array}$ & Sierra Leone \\
\hline Lal [31] & LA & $\begin{array}{c}\mathrm{FC}=0.065+(0.004 \times \mathrm{Cl}) \\
\mathrm{PWP}=0.006+(0.003 \times \mathrm{Cl})\end{array}$ & Nigeria \\
\hline Pidgeon [32] & PI & $\begin{array}{c}\mathrm{FC}=\left(100 \times \mathrm{w}_{F C}-3.77\right) \div 95 \\
\text { where: } \mathrm{w}_{F C}=0.0738+(0.0016 \times \mathrm{Si})+ \\
(0.003 \times \mathrm{Cl})+(0.03 \times \mathrm{SOC}) \\
\mathrm{PWP}=-0.0419+(0.0019 \times \mathrm{Si})+ \\
(0.0039 \times \mathrm{Cl})+(0.009 \times \mathrm{SOC})\end{array}$ & Uganda \\
\hline
\end{tabular}
in this study.

where $\mathrm{FC}\left(\%, \mathrm{~kg} \mathrm{~kg}^{-1}\right)$ is the gravimetric soil moisture content at field capacity, $\mathrm{PWP}\left(\%, \mathrm{~kg} \mathrm{~kg}^{-1}\right)$ is the gravimetric soil moisture content at permanent wilting point, $\mathrm{Cl}(\%)$ is clay content, $\mathrm{Si}(\%)$ is silt content, $\mathrm{Sa}(\%)$ is sand content and SOC $(\%)$ is soil organic carbon content.

\section{Results and Discussion}

\subsection{Description of Soil Datasets}

\subsubsection{Distribution of USDA Soil Textural Classes}

Newly developed PTFs still need to be tested for suitability over a wide range of soil types from different climatic conditions before they can be utilized with confidence to estimate soil moisture content at FC and PWP. The soil horizons were classified according to the textural triangle of the United States Department of Agriculture (USDA) classification scheme [59]. The results showed a uniform distribution of eleven textural classes across the development and validation datasets (Table 2). Furthermore, clay, sandy loam and sandy clay loam were the dominant textural classes across both the development and validation datasets, respectively. These findings indicate that the datasets used in this study represent a wide range of textural classes for the most typical soil types found in South Africa $[58,68]$. Thus, these datasets are suitable for the development and validation of PTFs for the estimation of soil moisture content at FC and PWP under a wide range of agro-climatic conditions in South Africa. 
Table 2. Percentage distribution of USDA soil textural classes between development and validation datasets.

\begin{tabular}{ccc}
\hline \multirow{2}{*}{ Textural Class } & \multicolumn{2}{c}{ Frequency (\%) } \\
\cline { 2 - 3 } & Development Dataset $(\boldsymbol{n = 3 1 7 1 )}$ & Validation Dataset $(\boldsymbol{n}=\mathbf{3 1 3 6})$ \\
\hline Clay & 22.93 & 21.01 \\
Clay loam & 7.03 & 7.78 \\
Loam & 4.82 & 5.10 \\
Loam sand & 9.93 & 10.17 \\
Sand & 8.14 & 7.81 \\
Sandy clay & 4.95 & 4.78 \\
Sandy clay loam & 18.92 & 20.09 \\
Sandy loam & 20.47 & 20.63 \\
Silty clay & 0.85 & 0.86 \\
Silty clay loam & 1.10 & 0.92 \\
Silty loam & 0.85 & 0.83 \\
\hline
\end{tabular}

\subsubsection{Descriptive Statistics of Soil Datasets}

The soil physico-chemical properties for all sampling sites illustrated a wide range of soil types attributed to the heterogeneity of South African parent material, geology and climatic conditions (Table 3). The summary statistics of all datasets showed that sand content ranged from $2-97 \%$, and silt, clay and SOC content ranged from $1-68 \%, 1-83 \%$ and $0.01-11.7 \%$, respectively. The results showed that soil moisture content at FC and PWP ranged from $0.01-0.50 \mathrm{~kg} \mathrm{~kg}^{-1}$ and from $0-0.31 \mathrm{~kg} \mathrm{~kg}^{-1}$, respectively. The development and validation datasets had similar ranges for all soil physico-chemical properties.

Table 3. Descriptive statistics for all datasets, development datasets and validation.

\begin{tabular}{ccccccc}
\hline Dataset & Parameter & $\boldsymbol{n}$ & Min & Max & Mean & Std. Dev \\
\hline \multirow{5}{*}{ All data } & Sand (\%) & 6307 & 2.00 & 97.00 & 55.06 & 23.69 \\
& Silt (\%) & 6307 & 1.00 & 68.00 & 16.40 & 11.78 \\
& Clay (\%) & 6307 & 1.00 & 83.00 & 27.25 & 17.27 \\
& SOC (\%) & 6307 & 0.01 & 11.70 & 0.73 & 0.80 \\
& FC (kg kg $\left.{ }^{-1}\right)$ & 6307 & 0.01 & 0.50 & 0.18 & 0.10 \\
& PWP (kg kg $\left.{ }^{-1}\right)$ & 6307 & 0.00 & 0.31 & 0.11 & 0.07 \\
\hline \multirow{5}{*}{ Development } & Sand (\%) & 3171 & 2.00 & 97.00 & 54.72 & 24.06 \\
data & Silt (\%) & 3171 & 1.00 & 64.00 & 16.34 & 11.84 \\
& Clay (\%) & 3171 & 1.00 & 83.00 & 27.65 & 17.61 \\
& SOC (\%) & 3171 & 0.01 & 9.36 & 0.75 & 0.82 \\
& FC (kg kg $\left.{ }^{-1}\right)$ & 3171 & 0.01 & 0.50 & 0.18 & 0.10 \\
& PWP (kg kg $\left.{ }^{-1}\right)$ & 3171 & 0.00 & 0.31 & 0.11 & 0.07 \\
\hline \multirow{5}{*}{ Validation } & Sand (\%) & 3136 & 2.00 & 97.00 & 55.39 & 23.30 \\
data & Silt (\%) & 3136 & 1.00 & 68.00 & 16.45 & 11.72 \\
& Clay (\%) & 3136 & 1.00 & 80.00 & 26.85 & 16.91 \\
& SOC (\%) & 3136 & 0.01 & 11.70 & 0.72 & 0.78 \\
& FC (kg kg $\left.{ }^{-1}\right)$ & 3136 & 0.01 & 0.50 & 0.17 & 0.10 \\
& PWP (kg kg $\left.{ }^{-1}\right)$ & 3136 & 0.00 & 0.30 & 0.11 & 0.07 \\
\hline
\end{tabular}

where $n$ is the number of soil samples, Min is minimum, Max is maximum, Std. dev is the standard deviation, SOC is the soil organic carbon, FC is soil moisture at field capacity, and PWP is soil moisture at permanent wilting point.

\subsection{Correlation Analysis}

Prior to the development of the PTFs for estimating soil moisture content at FC and PWP, it was critical to understand the relationships between FC, PWP and selected soil physico-chemical properties to inform the choice of possible explanatory variables to be included in the new PTFs. The correlation coefficients among the soil physico-chemical properties of the development dataset are presented in Table 4 . The results showed that both soil moisture at FC and PWP had significant $(p<0.01)$ and positive correlations 
with clay, silt and SOC, but were significantly and negatively correlated with sand. These findings confirm that small particles such as clay and silt have a higher water holding capacity as a result of their relatively larger surface area, as well as their large number of small pores that enhance the soil moisture absorption capacity $[41,59,69]$. Furthermore, the results indicate that soils with high SOC have a higher water absorption capacity as the result of the larger surface area of SOC that enhances the moisture absorption capacity of the soil [26,70]. Moreover, SOC acts as a binding agent that improves the moisture absorption capacity of the soil [70]. These findings agree with earlier studies that reported that silt, clay, and SOC are significantly and positively correlated to both FC and PWP [16,17,21,42,71,72]. The findings of this study suggest that sand, silt, clay, and SOC content can be used as the explanatory variables in the estimation of soil moisture content at both FC and PWP.

Table 4. Pearson's correlations between measured soil physico-chemical properties.

\begin{tabular}{ccccccc}
\hline Parameters & Sand & Silt & Clay & SOC & FC & PWP \\
\hline Sand & 1.00 & & & & & \\
Silt & $-0.70^{* *}$ & 1.00 & & & & \\
Clay & $-0.87^{* *}$ & $0.27^{* *}$ & 1.00 & & & \\
SOC & $-0.40^{* *}$ & $0.37^{* *}$ & $0.27^{* *}$ & 1.00 & & \\
FC & $-0.83^{* *}$ & $0.43^{* *}$ & $0.82^{* *}$ & $0.35^{* *}$ & 1.00 & \\
PWP & $-0.83^{* *}$ & $0.35^{* *}$ & $0.87^{* *}$ & $0.34^{* *}$ & $0.94^{* *}$ & 1.00 \\
\hline
\end{tabular}

where SOC is the soil organic carbon, FC is soil moisture content at the field capacity, PWP is soil moisture content at permanent wilting point and ${ }^{* *}$ is correlation significant level at 0.01 .

\subsection{New PTFs for Estimating Soil Moisture Content at FC and PWP}

The stepwise multiple linear regressions were used to develop new PTFs for estimating soil moisture content in FC and PWP from readily available soil physico-chemical properties (Table 5). The results indicated that the new PTF for estimating soil moisture content at FC explained $73 \%$ of the total variation while the new PTF for estimating soil moisture content at PWP explained $79 \%$ of the total variation. The results further revealed that clay, SOC and silt content were the most significant $(p<0.001)$ explanatory variables for the prediction of soil moisture content at FC and PWP, with standard errors less than $0.002 \mathrm{~kg} \mathrm{~kg}^{-1}$ suggesting the robustness of these new PTFs. These findings agreed with the previous studies that reported that clay, SOC and silt content were the key input variables for the reliable estimation of soil moisture content at FC and PWP [16,26,32].

Table 5. Results of the stepwise multiple linear regressions for the new PTFs.

\begin{tabular}{cccccc}
\hline Parameter & Variable & $S E$ & $p$ & $r^{2}$ & Output Equations \\
\hline FC $\left(\mathrm{kg} \mathrm{kg}^{-1}\right)$ & Constant & 0.002 & $<0.001$ & 0.73 & $\mathrm{FC}=0.014+(0.005 \times \mathrm{Cl})+(0.009 \times \mathrm{SOC})+(0.002 \times \mathrm{Si})$ \\
& Clay & 0.000 & 0.000 & & \\
& SOC & 0.001 & $<0.001$ & & \\
& Silt & 0.000 & $<0.001$ & & $\mathrm{PWP}=(0.003 \times \mathrm{Cl})+(0.001 \times \mathrm{Si})+(0.007 \times \mathrm{SOC})$ \\
\hline PWP $\left(\mathrm{kg} \mathrm{kg}^{-1}\right)$ & Constant & 0.001 & 0.894 & 0.79 & \\
& Clay & 0.000 & 0.000 & & \\
& Silt & 0.000 & $<0.001$ & & \\
& SOC & 0.001 & $<0.001$ & & \\
\hline
\end{tabular}

where SE is the standard error $\left(\mathrm{kg} \mathrm{kg}^{-1}\right), p$ is the level of significance, $r^{2}$ is the coefficient of determination, SOC (\%) is the soil organic carbon, FC $\left(\mathrm{kg} \mathrm{kg}^{-1}\right)$ is the gravimetric soil moisture content at field capacity, PWP $\left(\mathrm{kg} \mathrm{kg}^{-1}\right)$ is the gravimetric soil moisture content at permanent wilting point, $\mathrm{Cl}(\%)$ is clay content $(\%)$ and $\mathrm{Si}(\%)$ is silt content.

\subsection{Evaluation of PTFs for Estimating FC and PWP}

\subsubsection{Performance of the PTFs for Estimating Soil Moisture Content at FC and PWP}

To evaluate the performance of new PTFs for estimating soil moisture content at FC and PWP, comparisons were performed for soil moisture content measured and estimated at FC and PWP using an independent dataset. Furthermore, five existing PTFs for estimating 
soil moisture content at FC and PWP were also evaluated using an identical validation dataset. The results indicated reasonable relationships between measured and estimated soil moisture content at FC and PWP for all PTFs evaluated (Figures 2 and 3, respectively; Table 6).
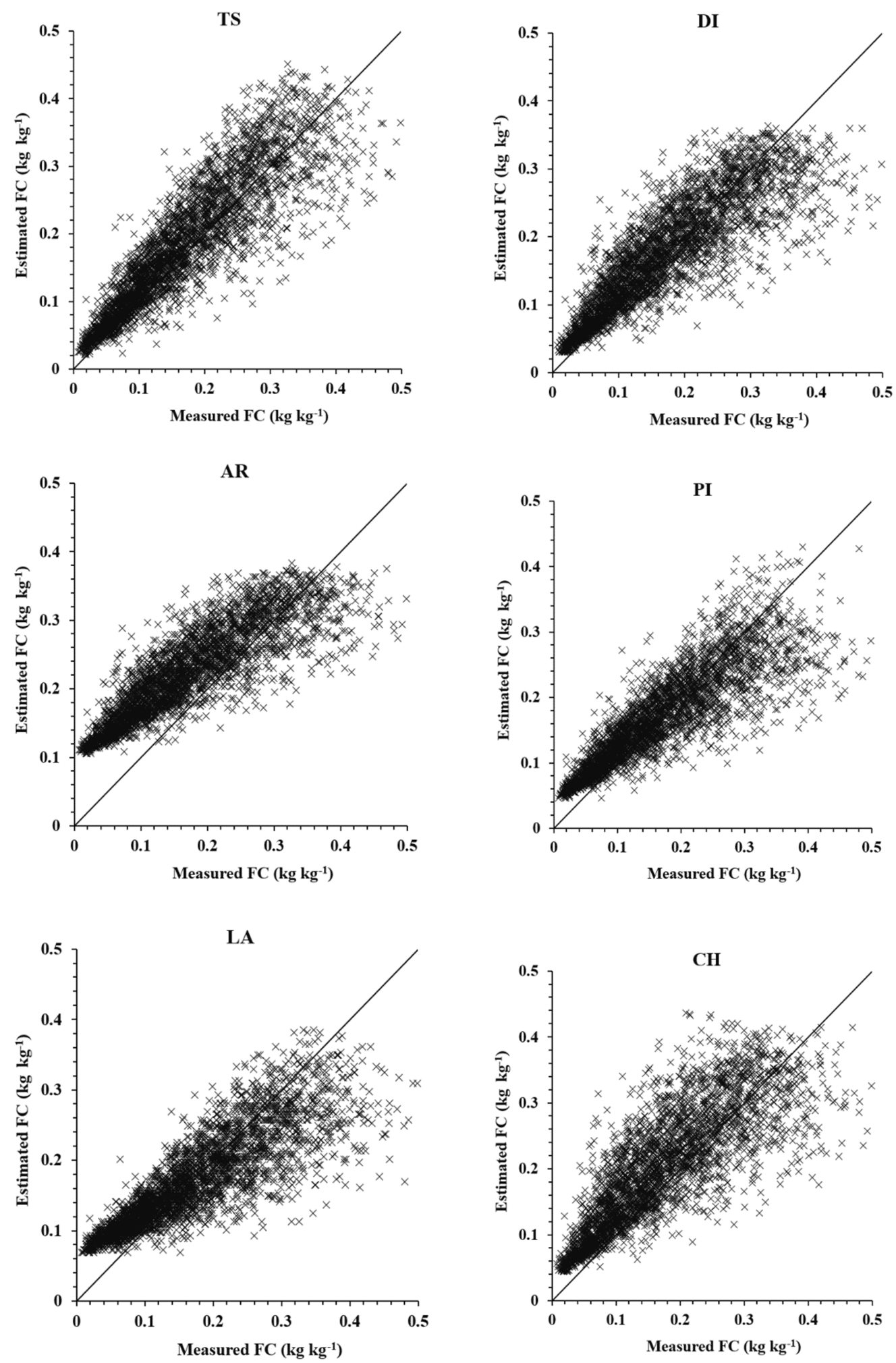

Figure 2. Comparison between measured and estimated soil moisture contents at field capacity (FC) using six different pedotransfer functions (PTFs). TS is the new PTF developed in this study, DI is the PTF of Dijkerman [25], AR is the PTF of Arruda et al. [30], PI is the PTF of Pidgeon [32], LA is the PTF of Lal [31] and CH is the PTF of Chakraborty et al. [33]. 

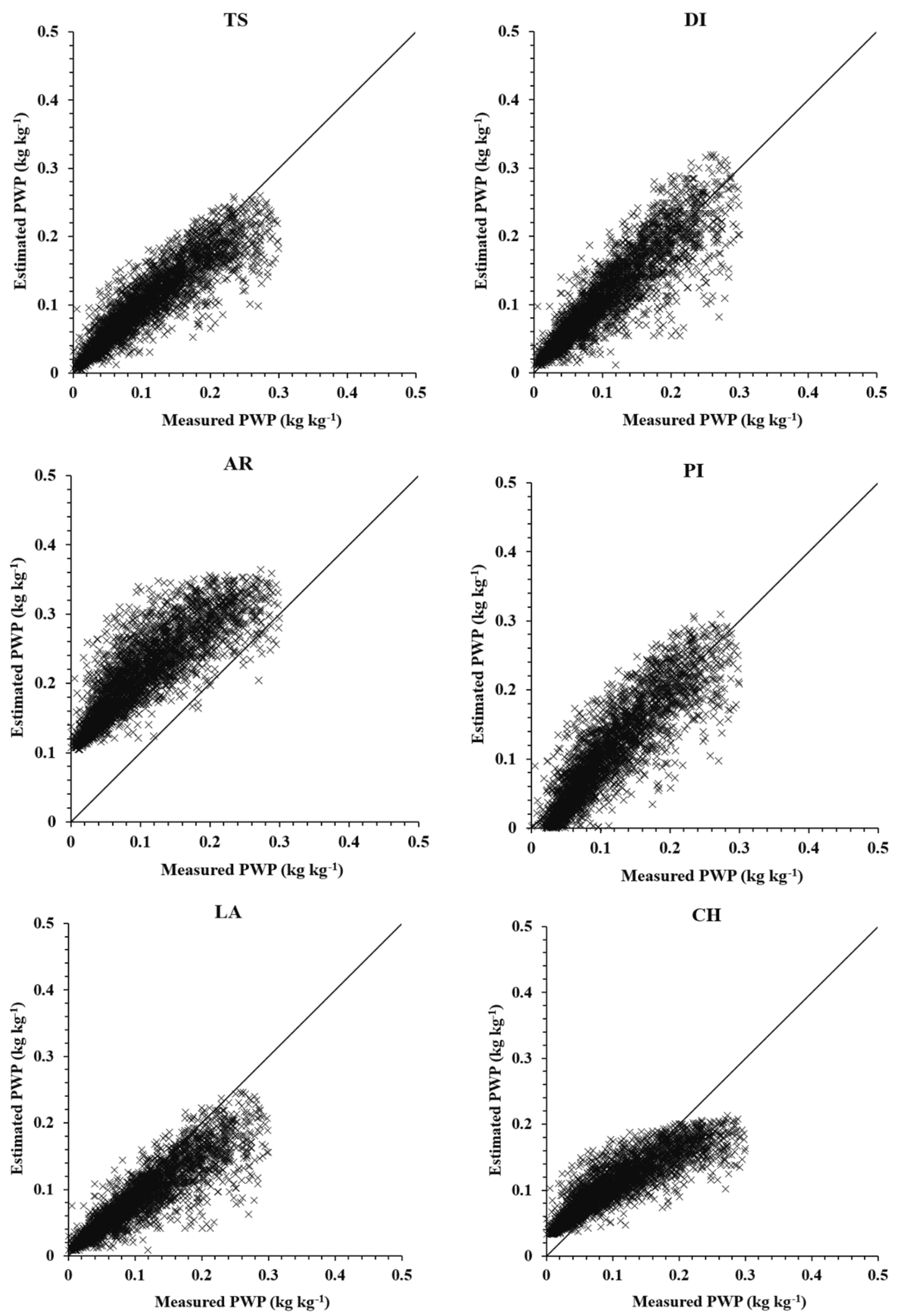

Figure 3. Comparison between measured and estimated soil moisture contents at permanent wilting point (PWP) using six different pedotransfer functions (PTFs). TS is the new PTF developed in this study, DI is the PTF of Dijkerman [25], AR is the PTF of Arruda et al. [30], PI is the PTF of Pidgeon [32], LA is the PTF of Lal [31] and CH is the PTF of Chakraborty et al. [33]. 
Table 6. Performance of the new and well-established PTFs using the validation dataset (PTFs were ranked based on RMSE).

\begin{tabular}{|c|c|c|c|c|c|c|c|}
\hline Parameters & PTFs & $m$ & $\begin{array}{c}c \\
\left(\mathrm{~kg} \mathrm{~kg}^{-1}\right)\end{array}$ & $r^{2}$ & $\begin{array}{c}\text { RMSE } \\
\left(\mathrm{kg} \mathrm{kg}^{-1}\right)\end{array}$ & $\begin{array}{c}\text { MBE } \\
\left(\mathrm{kg} \mathrm{kg}^{-1}\right)\end{array}$ & $d$ \\
\hline \multirow[t]{6}{*}{ FC } & TS & 0.853 & 0.039 & 0.77 & 0.047 & 0.002 & 0.93 \\
\hline & DI & 0.700 & 0.054 & 0.72 & 0.052 & 0.003 & 0.91 \\
\hline & $\mathrm{AR}$ & 0.575 & 0.125 & 0.73 & 0.052 & 0.003 & 0.81 \\
\hline & PI & 0.632 & 0.063 & 0.72 & 0.053 & 0.003 & 0.90 \\
\hline & LA & 0.576 & 0.072 & 0.71 & 0.053 & 0.003 & 0.88 \\
\hline & $\mathrm{CH}$ & 0.729 & 0.076 & 0.65 & 0.058 & 0.003 & 0.87 \\
\hline \multirow[t]{6}{*}{ PWP } & TS & 0.759 & 0.021 & 0.82 & 0.029 & 0.001 & 0.96 \\
\hline & PI & 1.025 & 0.010 & 0.81 & 0.030 & 0.001 & 0.94 \\
\hline & LA & 0.667 & 0.015 & 0.80 & 0.030 & 0.001 & 0.90 \\
\hline & DI & 0.867 & 0.019 & 0.80 & 0.030 & 0.001 & 0.56 \\
\hline & $\mathrm{CH}$ & 0.547 & 0.050 & 0.76 & 0.033 & 0.001 & 0.96 \\
\hline & AR & 0.775 & 0.133 & 0.72 & 0.036 & 0.001 & 0.61 \\
\hline
\end{tabular}

where PTFs is pedotransfer functions, $m$ the slope, $c$ the $y$-intercept, $r^{2}$ the coefficient of determination, RMSE the root mean square error, MBE the mean bias error, $d$ index of agreement, FC and PWP are the soil moisture content at field capacity and permanent wilting point, respectively, whilst TS is the new PTF developed in this study, DI is the PTF of Dijkerman [25], AR is the PTF of Arruda et al. [30], PI is the PTF of Pidgeon [32], LA is the PTF of Lal [31] and CH is the PTF of Chakraborty et al. [33].

The $r^{2}$ values for the well-established PTFs ranged from $0.65-0.72$ for FC and 0.72-0.81 for PWP, whilst those developed in this study were 0.77 and 0.82 for FC and PWP, respectively. Amongst the existing PTFs, the PTF of Dijkerman [25] performed better (RMSE = $0.052 \mathrm{~kg} \mathrm{~kg}^{-1}$ ) in the estimation of soil moisture content at FC while the PTF of Pidgeon [32] performed better $\left(\mathrm{RMSE}=0.030 \mathrm{~kg} \mathrm{~kg}^{-1}\right)$ in the estimation of soil moisture content at PWP. In contrast, the PTF of Chakraborty et al. [33] had the worst performance in the estimation of soil moisture content at FC (RMSE $=0.058 \mathrm{~kg} \mathrm{~kg}^{-1}$ ) and the PTF of Arruda et al. [30] was the worst in the estimation of soil moisture content at PWP (RMSE $\left.=0.036 \mathrm{~kg} \mathrm{~kg}^{-1}\right)$. The findings of this study agree with those of Botula et al. [13] who reported RMSE values of $0.053,0.040,0.075$ and $0.045 \mathrm{~kg} \mathrm{~kg}^{-1}$ for the PTFs of Arruda et al. [30], Dijkerman [25], Lal [31] and Pidgeon [32], respectively, for estimation of soil moisture content at FC for soils in the Democratic Republic of the Congo. Furthermore, their study reported RMSE values of $0.021,0.032,0.058$ and $0.028 \mathrm{~kg} \mathrm{~kg}^{-1}$ for the PTFs of Arruda et al. [30], Dijkerman [25], Lal [31] and Pidgeon [32], respectively, for estimation of soil moisture content at PWP [13].

The results of this study indicate better performance of the new PTFs developed with RMSE values of 0.047 and $0.029 \mathrm{~kg} \mathrm{~kg}^{-1}$ for soil moisture content at FC and PWP, respectively. These findings suggest that PTFs derived locally using a large number of soil horizons acquired from different soil depths, soil types, geographic and climatic locations improved the estimation of soil moisture content at FC and PWP. Furthermore, this study indicates restricted applicability, reliability and transferability of the existing PTFs across different regions, thus the need for the development of new PTFs for each specific region is indisputable. The findings also confirmed that the PTFs applied outside the soils and climatic conditions from which they were derived may result in poor performance $[8,13,18,20,73]$. This is in agreement with previous studies that reported better performance of locally-derived PTFs over the existing PTFs that were developed for specific regions with different climatological and pedological properties [9,12,13,39-43].

The results showed that soil moisture content at PWP could be estimated with a higher degree of accuracy $\left(r^{2}=0.82\right.$ and RMSE $\left.=0.029 \mathrm{~kg} \mathrm{~kg}^{-1}\right)$ compared to FC $\left(r^{2}=0.77\right.$ and RMSE $=0.047 \mathrm{~kg} \mathrm{~kg}^{-1}$ ) using the new PTFs that were developed in this study. The relatively lower accuracy of estimated soil moisture content at PWP could be attributed to the lack of information regarding soil structure in these new PTFs that could have been probably provided by including the bulk density as one of the explanatory variables. These findings are in agreement with previous studies that reported better performance of the PTFs in the estimation of soil moisture content at PWP compared to FC $[13,73,74]$. The results of 
this study indicate that the performance of all PTFs evaluated decreased with an increase in gravimetric soil moisture content. The relatively lower performance of the PTFs at the wetter range could be attributed to soil water retention at the wet range being primarily controlled by the soil structure, whereas, at the dry range, it is primarily controlled by soil texture [74]. Thus, since all PTFs evaluated in this study did not include bulk density (an indicator of soil structure) and used disturbed soil samples for the determination of soil moisture content at FC and PWP, these PTFs did not explicitly take the effects of soil structure on soil water retention into consideration.

\subsubsection{Overall Discussion}

The new PTFs developed in this study were capable of estimating soil moisture content at FC and PWP from particle size distribution and SOC with acceptable levels of confidence. These new PTFs are time-efficient and could reduce the cost and labour requirements in the estimation of soil moisture content at FC and PWP that are required by biophysical models to solve numerous challenges related to soil water in the fields of agriculture, ecology, environment and hydrology $[13,14,37]$. The new PTFs are expected to improve the estimation of the plant-available water, not only in South Africa where the need for efficient water use is of paramount importance under the threat of water scarcity but also in other regions facing data scarcity that have similar soil types and climatic conditions. Thus, due to the range of conditions for which these new PTFs were derived, they should be used with caution in other regions to estimate soil moisture content at FC and PWP from minimal soil physico-chemical properties that are usually available from surveys or are easily measured in most countries of the world. Moreover, this study is expected to raise awareness to the model users regarding the potential errors and implications attributed to the use of the ready-to-use PTFs within the models that were developed for specific regions with different soil types and climatic conditions.

To the best of our knowledge, this is the first study in southern Africa that has developed new PTFs and evaluated them against existing ones for the estimation of soil moisture content at FC and PWP using a large number of soil horizons (6307) acquired from different soil types, geographic and climatic conditions. Thus, for the wide applicability of the new PTFs that were developed in this study, a soil moisture retentivity (SMR) calculator that is user-friendly, quick and reliable was developed. In this calculator, a user is required to enter the percentages of clay, silt and SOC content to calculate the soil moisture content at FC and PWP instantaneously. The SMR spreadsheet is freely available on request from the authors.

\section{Conclusions}

The application of biophysical models requires the knowledge of soil moisture content at field capacity and permanent wilting point for each soil horizon. However, measurements of these soil hydraulic properties are time-consuming, labour-intensive, expensive and sometimes impractical or financially unattainable, especially in regional studies. Therefore, this study was undertaken to develop new pedotransfer functions for the estimation of soil moisture content at FC and PWP for a wide range of soil types and climatic conditions in South Africa. These new PTFs were evaluated and compared with five well-established PTFs using an independent dataset.

This study indicated a limited transferability of PTFs across different regions, particularly in regions with different geological, climatic and soil bio-physico-chemical properties to those of their origins. Therefore, existing PTFs still need to be tested for suitability before they can be utilized with confidence to estimate soil moisture content at FC and PWP for regions with different soil types and climatic conditions from which they were derived. Furthermore, the development of new PTFs for each region using a large number of soil horizons acquired over a wide range of soil types, geographic and climatic conditions is indisputable for the improved estimation of soil moisture content at FC and PWP. 
The PTFs developed in this study reliably estimate soil moisture content at FC and PWP over a wide range of soil types and climatic conditions found in South Africa. These new PTFs are quick, reliable and could reduce the cost and labour requirements in the estimation of soil moisture content at FC and PWP required by biophysical models. Due to the large soil datasets and wide range of soil types, geographic and climatic conditions over which these PTFs were derived, they can be applied with caution in other regions facing data scarcity but with similar soil types and climatic conditions. To allow wide applicability of the new PTFs that were derived in this study, a quick, reliable and userfriendly soil moisture retentivity calculator was developed that uses clay, silt and SOC content as input requirements to compute soil moisture content at FC and PWP. For future studies, it is recommended that undisturbed soil samples are collected for the determination of soil moisture content at FC and PWP to improve the accuracy of the PTFs. It is also recommended that future studies explore the benefits of the development of PTFs for each specific agro-climatic condition of the region, unlike the current study where we developed the generic PTFs for the whole of South African soils.

Author Contributions: Conceptualization, L.M., T.M. and M.E.M.; methodology, L.M.; software, L.M. and G.D.N.; validation, L.M., T.M., D.G.P., G.D.N. and M.E.M.; formal analysis, L.M.; writingoriginal draft preparation, L.M.; writing — review and editing, L.M., T.M., D.G.P. and M.E.M. All authors have read and agreed to the published version of the manuscript.

Funding: This research was funded by the European Union's H2020 research and innovation programme, Grant Agreement No. 727201.

Institutional Review Board Statement: Not applicable.

Informed Consent Statement: Not applicable.

Data Availability Statement: The data presented in this study are available on request from the corresponding author.

Acknowledgments: The ARC-Natural Resources and Engineering is gratefully acknowledged for the provision of data, and we thank Marjan van der Walt her assistance with data retrieval. We thank the Land Type Survey personnel for soil classifications and collection of soil samples. We thank Thomas Fyfield for editorial assistance.

Conflicts of Interest: The authors declare no conflict of interest.

\section{References}

1. da Silva, A.C.; Armindo, R.A.; dos Santos Brito, A.; Schaap, M.G. SPLINTEX: A physically-based pedotransfer function for modeling soil hydraulic functions. Soil Tillage Res. 2017, 174, 261-272. [CrossRef]

2. Steduto, P.; Raes, D.; Hsiao, T.C.; Fereres, E.; Heng, L.K.; Howell, T.A.; Evett, S.R.; Rojas-Lara, B.A.; Farahani, H.J.; Izzi, G. Concepts and applications of AquaCrop: The FAO crop water productivity model. In Crop Modeling and Decision Support; Springer: New York, NY, USA, 2009; pp. 175-191.

3. Keating, B.A.; Carberry, P.S.; Hammer, G.L.; Probert, M.E.; Robertson, M.J.; Holzworth, D.; Huth, N.I.; Hargreaves, J.N.G.; Meinke, H.; Hochman, Z. An overview of APSIM, a model designed for farming systems simulation. Eur. J. Agron. 2003, 18, 267-288. [CrossRef]

4. Stöckle, C.O.; Donatelli, M.; Nelson, R. CropSyst, a cropping systems simulation model. Eur. J. Agron. 2003, 18, $289-307$. [CrossRef]

5. Jones, J.W.; Hoogenboom, G.; Porter, C.H.; Boote, K.J.; Batchelor, W.D.; Hunt, L.A.; Wilkens, P.W.; Singh, U.; Gijsman, A.J; Ritchie, J.T. The DSSAT cropping system model. Eur. J. Agron. 2003, 18, 235-265. [CrossRef]

6. Saxton, K.E.; Willey, P.H. The SPAW model for agricultural field and pond hydrologic simulation. Watershed Model. 2005, 400-435.

7. Douglas-Mankin, K.R.; Srinivasan, R.; Arnold, J.G. Soil and water assessment tool (SWAT) Model: Current developments and applications. Trans. ASABE 2010, 53, 1423-1431. [CrossRef]

8. Rab, M.A.; Chandra, S.; Fisher, P.D.; Robinson, N.J.; Kitching, M.; Aumann, C.D.; Imhof, M. Modelling and prediction of soil water contents at field capacity and permanent wilting point of dryland cropping soils. Soil Res. 2011, 49, 389-407. [CrossRef]

9. Buccigrossi, F.; Caliandro, A.; Rubino, P.; Mastro, M.A. Testing some pedo-transfer functions (PTFs) in Apulia Region. Evaluation on the basis of soil particle size distribution and organic matter content for estimating field capacity and wilting point. Ital. J. Agron. 2010, 5, 367-381. [CrossRef] 
10. Aliku, O.O.; Oshunsanya, S.O. Assessment of the SOILWAT model for predicting soil hydro-physical characteristics in three sagro-ecological zones in Nigeria. Int. Soil Water Conserv. Res. 2018, 6, 131-142. [CrossRef]

11. Walczak, R.; Witkowska-Walczak, B.; Sławiński, C. Comparison of correlation models for the estimation of the water retention characteristics of soil. Int. Agrophys. 2001, 16, 79-82.

12. Castellini, M.; Iovino, M. Pedotransfer functions for estimating soil water retention curve of sicilian soils. Arch. Agron. Soil Sci. 2019, 65, 1401-1416. [CrossRef]

13. Botula, Y.D.; Cornelis, W.M.; Baert, G.; Van Ranst, E. Evaluation of pedotransfer functions for predicting water retention of soils in lower congo (D.R. Congo). Agric. Water Manag. 2012, 111, 1-10. [CrossRef]

14. Wösten, J.H.M.; Verzandvoort, S.J.E.; Leenaars, J.G.B.; Hoogland, T.; Wesseling, J.G. Soil hydraulic information for River Basin studies in semi-arid regions. Geoderma 2013, 195-196, 79-86. [CrossRef]

15. Hardie, M.A.; Lisson, S.; Doyle, R.B.; Cotching, W.E. Evaluation of rapid approaches for determining the soil water retention function and saturated hydraulic conductivity in a hydrologically complex soil. Soil Tillage Res. 2013, 130, 99-108. [CrossRef]

16. Santra, P.; Kumar, M.; Kumawat, R.N.; Painuli, D.K.; Hati, K.M.; Heuvelink, G.B.M.; Batjes, N.H. Pedotransfer functions to estimate soil water content at field capacity and permanent wilting point in hot arid Western India. J. Earth Syst. Sci. 2018, 127, 1-16. [CrossRef]

17. Qiao, J.; Zhu, Y.; Jia, X.; Huang, L.; Shao, M. Pedotransfer functions for estimating the field capacity and permanent wilting point in the critical zone of the Loess Plateau, China. J. Soils Sediments 2019, 19, 140-147. [CrossRef]

18. Kätterer, T.; Andrén, O.; Jansson, P.E. Pedotransfer functions for estimating plant available water and bulk density in swedish agricultural soils. Acta Agric. Scand. Sect. B Soil Plant. Sci. 2006, 56, 263-276. [CrossRef]

19. Mohanty, M.; Sinha, N.K.; Painuli, D.K.; Bandyopadhyay, K.K.; Hati, K.M.; Sammi Reddy, K.; Chaudhary, R.S. Modelling soil water contents at field capacity and permanent wilting point using artificial neural network for Indian Soils. Natl. Acad. Sci. Lett. 2015, 38, 373-377. [CrossRef]

20. Tomasella, J.; Hodnett, M.G. Estimating soil water retention characteristics from limited data in Brazilian Amazonia. Soil Sci. 1998, 163, 190-202. [CrossRef]

21. Bortolini, D.; Albuquerque, J.A. Estimation of the retention and availability of water in soils of the state of Santa Catarina. Revista Brasileira de Ciência do Solo 2018, 42, 1-13. [CrossRef]

22. Buitenwerf, R.; Kulmatiski, A.; Higgins, S.I. Soil water retention curves for the major soil types of the Kruger National Park. Koedoe 2014, 56, 1-9. [CrossRef]

23. Mbah, C.N. Determining the field capacity, wilting point and available water capacity of some southeast nigerian soils using soil saturation from capillary rise. Niger. J. Biotechnol. 2012, 24, 41-47.

24. Khodaverdiloo, H.; Homaee, M.; van Genuchten, M.T.; Dashtaki, S.G. Deriving and validating pedotransfer functions for some calcareous soils. J. Hydrol. 2011, 399, 93-99. [CrossRef]

25. Dijkerman, J.C. An ustult-aquult-tropept catena in Sierra Leone, West Africa, II. Land qualities and land evaluation. Geoderma 1988, 42, 29-49. [CrossRef]

26. Saxton, K.E.; Rawls, W.J. Soil water characteristic estimates by texture and organic matter for hydrologic solutions. Soil Sci. Soc. Am. J. 2006, 70, 1569-1578. [CrossRef]

27. van Huyssteen, C.W. A Review of advances in hydropedology for application in South Africa. S. Afr. J. Plant. Soil 2008, 25, 245-254. [CrossRef]

28. Hutson, J.L. Water retentivity of some South African soils in relation to particle size criteria and bulk density. S. Afr. J. Plant. Soil 1986, 3, 151-155. [CrossRef]

29. Dharumarajan, S.; Hegde, R.; Lalitha, M.; Kalaiselvi, B.; Singh, S.K. Pedotransfer functions for predicting soil hydraulic properties in semi-arid regions of Karnataka Plateau, India. Curr. Sci. 2019, 116, 1237-1246. [CrossRef]

30. Arruda, F.B.; Zullo Junior, J.; de Oliveira, J.B. Soil parameters for calculating available water based on soil texture. Revista Brasileira de Ciência do Solo 1987, 11, 11-15.

31. Lal, R. Physical properties and moisture retention characteristics of some nigerian soils. Geoderma 1978, 21, 209-223. [CrossRef]

32. Pidgeon, J.D. The measurement and prediction of available water capacity of ferrallitic soils in Uganda. J. Soil Sci. 1972, 23, 431-441. [CrossRef]

33. Chakraborty, D.; Mazumdar, S.P.; Garg, R.N.; Banerjee, S.; Santra, P.; Singh, R.; Tomar, R.K. Pedotransfer functions for predicting points on the moisture retention curve of indian soils. Indian J. Agric. Sci. 2011, 81, 1030.

34. Rawles, W.J.; Brakensiek, D.L. Estimating soil water retention from soil properties. J. Irrig. Drain. Div. 1982, 108, 166-171. [CrossRef]

35. Saxton, K.E.; Rawls, W.J.; Romberger, J.S.; Papendick, R.I. Estimating generalized soil-water characteristics from texture. Soil Sci. Soc. Am. J. 1986, 50, 1031-1036. [CrossRef]

36. Pachepsky, Y.; Rawls, W.J. Development of Pedotransfer Functions in Soil Hydrology; Elsevier: Amsterdam, The Netherlands, 2004; ISBN 0080530362.

37. Adhikary, P.P.; Chakraborty, D.; Kalra, N.; Sachdev, C.B.; Patra, A.K.; Kumar, S.; Tomar, R.K.; Chandna, P.; Raghav, D.; Agrawal, K. Pedotransfer functions for predicting the hydraulic properties of indian soils. Soil Res. 2008, 46, 476-484. [CrossRef]

38. Gupta, S.; Larson, W.E. Estimating soil water retention characteristics from particle size distribution, organic matter percent, and bulk density. Water Resour. Res. 1979, 15, 1633-1635. [CrossRef] 
39. Hodnett, M.G.; Tomasella, J. Marked differences between van genuchten soil water-retention parameters for temperate and tropical soils: A new water-retention pedo-transfer functions developed for tropical soils. Geoderma 2002, 108, 155-180. [CrossRef]

40. Wagner, B.; Tarnawski, V.R.; Hennings, V.; Müller, U.; Wessolek, G.; Plagge, R. Evaluation of pedo-transfer functions for unsaturated soil hydraulic conductivity using an independent data set. Geoderma 2001, 102, 275-297. [CrossRef]

41. Mdemu, M.V. Evaluation and development of pedotransfer functions for estimating soil water holding capacity in the tropics: The case of Sokoine University of Agriculture Farm in Morogoro, Tanzania. J. Geogr. Geol. 2015, 7, 1-9. [CrossRef]

42. Hegde, R.; Singh, S.K. Evaluation of soil moisture retention characteristics using pedo-transfer functions for soils of dry semi-arid region. Indian J. Soil Conserv. 2019, 47, 163-171.

43. Wösten, J.H.M.; Pachepsky, Y.A.; Rawls, W.J. Pedotransfer functions: Bridging the gap between available basic soil data and missing soil hydraulic characteristics. J. Hydrol. 2001, 251, 123-150. [CrossRef]

44. Sung, C.T.B.; Iba, J. Accuracy of the saxton-rawls method for estimating the soil water characteristics for mineral soils of Malaysia. Pertanika J. Trop. Agric. Sci. 2010, 33, 297-302.

45. Mohawesh, O.E. Assessment of pedotransfer functions (PTFs) in predicting soil hydraulic properties under arid and semi arid environments. Jordan J. Agric. Sci. 2013, 9.

46. Valdivia-Cea, W.; Holzapfel, E.; Rivera, D.; Paredes, J. Assessment of methods to determine soil characteristics for management and design of irrigation systems. J. Soil Sci. Plant. Nutr. 2017, 17, 735-750. [CrossRef]

47. Kaingo, J.; Tumbo, S.D.; Kihupi, N.I.; Mbilinyi, B.P. Prediction of soil moisture-holding capacity with support vector machines in dry subhumid tropics. Appl. Environ. Soil Sci. 2018, 2018, 9263296. [CrossRef]

48. Mills, A.J.; de Wet, R. Quantifying a sponge: The additional water in restored thicket. S. Afr. J. Sci. 2019, 115, 5-6. [CrossRef]

49. Davis, C.L.; Vincent, K. Climate Risk and Vulnerability: A Handbook for Southern Africa, 2nd ed.; CSIR: Pretoria, South Africa, 2017.

50. De Souza, K.; Kituyi, E.; Harvey, B.; Leone, M.; Murali, K.S.; Ford, J.D. Vulnerability to climate change in three hot spots in Africa and Asia: Key issues for policy-relevant adaptation and resilience-building research. Reg. Environ. Chang. 2015, 15, 747-753. [CrossRef]

51. Turco, M.; Palazzi, E.; Von Hardenberg, J.; Provenzale, A. Observed climate change hotspots. Geophys. Res. Lett. 2015, 42, 3521-3528. [CrossRef]

52. Schilling, J.; Hertig, E.; Tramblay, Y.; Scheffran, J. Climate change vulnerability, water resources and social implications in North Africa. Reg. Environ. Chang. 2020, 20, 1-12. [CrossRef]

53. Mottram, R.; JL, H.; PS, G. Water Retention by Some Natal Soils as Related to Soil Texture and Organic Matter Content; AGRIS: Klidi, Greece, 1981; Volume 10, pp. 47-50.

54. Hutson, J.L. Structural stability of diagnostic horizons in South African soils. S. Afr. J. Sci. 1982, 78, 453-454.

55. Schulze, R.E.; Hutson, J.L.; Cass, A. Hydrological characteristics and properties of soils in southern Africa 2: Soil water retention models. Water SA 1985, 11, 129-136.

56. Gebregiorgis, M.F.; Savage, M.J. Field, laboratory and estimated soil-water content limits. Water SA 2006, 32, 155-161. [CrossRef]

57. Land Type Survey Staff. 1:250,000 scale Land Type Survey of South Africa; Agricultural Research Council-Institute for Soil, Climate and Water: Pretoria, South Africa, 2000.

58. Soil Classification Working Group. Soil classification: A taxonomic system for South Africa. Mem. Agric. Nat. Resour. S. Afr. 1991, $15,1-262$.

59. Ditzler, C.; Scheffe, K.; Monger, H.C. USDA Handbook 18; US Government Printing Office: Washington, DC, USA, 2017 ; pp. 75-91.

60. Klute, A.; Page, A.L. Methods of Soil Analysis. Part 1. Physical and Mineralogical Methods; Part 2. Chemical and Microbiological Properties; American Society of Agronomy, Inc.: Maddison, WI, USA, 1986; pp. 383-411. ISBN 0891180729.

61. van Tol, J.J.; Dzene, A.R.; Le Roux, P.A.L.; Schall, R. Pedotransfer functions to predict atterberg limits for south african soils using measured and morphological properties. Soil Use Manag. 2016, 32, 635-643. [CrossRef]

62. Mather, J.R.; Yoshioka, G.A. The role of climate in the distribution of vegetation. Ann. Assoc. Am. Geogr. 1968, 58, 29-41. [CrossRef]

63. Chen, Z.; Wang, W.; Fu, J. Vegetation response to precipitation anomalies under different climatic and biogeographical conditions in China. Sci. Rep. 2020, 10, 1-16.

64. Hawinkel, P.; Thiery, W.; Lhermitte, S.; Swinnen, E.; Verbist, B.; Van Orshoven, J.; Muys, B. Vegetation response to precipitation variability in East Africa controlled by biogeographical factors. J. Geophys. Res. Biogeosci. 2016, 121, 2422-2444. [CrossRef]

65. Stewart, B.W.; Capo, R.C.; Chadwick, O.A. Effects of rainfall on weathering rate, base cation provenance, and sr isotope composition of hawaiian soils. Geochim. Cosmochim. Acta 2001, 65, 1087-1099. [CrossRef]

66. Agro-Climatology Database. Agricultural Research Council (ARC). 2020. Available online: http:/ /www.arc.agric.za/arc-iscw/ Pages/Climate-Monitoring-Services.aspx (accessed on 5 March 2020).

67. Willmott, C.J.; Ackleson, S.G.; Davis, R.E.; Feddema, J.J.; Klink, K.M.; Legates, D.R.; Odonnell, J.; Rowe, C.M. Statistics for the evaluation and comparison of models. J. Geophys. Res. Ocean. 1985, 90, 8995-9005. [CrossRef]

68. Schulze, R.E. Hydrology and Agrohydrology: A Text to Accompany the ACRU 3.00 Agrohydrological Modelling System; Water Research Commission: Pretoria, South Africa, 1995; ISBN 1868451364.

69. Leeper, G.W.; Uren, N.C. Soil Science: An Introduction; Melbourne University Press: Melbourne, Australia, 1993 ; ISBN 0522844642.

70. Charman, P.E.V.; Murphy, B.W. Soils: Their Properties and Management; Oxford University Press: Oxford, UK, 2007 ; pp. 83-96. ISBN 0195517628. 
71. Blaschek, M.; Roudier, P.; Poggio, M.; Hedley, C.B. Prediction of soil available water-holding capacity from visible near-infrared reflectance spectra. Sci. Rep. 2019, 9, 1-10.

72. Mandal, K.G.; Kundu, D.K.; Singh, R.; Kumar, A.; Rout, R.; Padhi, J.; Majhi, P.; Sahoo, D.K. Cropping practices, soil properties, pedotransfer functions and organic carbon storage at kuanria canal command area in India. SpringerPlus 2013, 2, 631-645. [CrossRef]

73. Mohamed, J.; Ali, S. Development and Comparative Analysis of Pedotransfer Functions for Predicting Soil Water Characteristic Content for Tunisian Soil. In Proceedings of the Tunisia-Japan Symposium on Science, Society and Technology (TJASSST), Sousse, Tunisia, 29 November-2 December 2006; pp. 170-178. Available online: http://www.weap21.org/downloads/ PedotransfertFunction_TJASSST_06.pdf (accessed on 10 June 2020).

74. Vereecken, H.; Kollet, S.; Simmer, C. Patterns in soil-vegetation-atmosphere systems: Monitoring, modeling, and data assimilation. Vadose Zone. J. 2010, 9, 821-827. [CrossRef] 